\title{
Penerapan Model Pembelajaran Inkuiri untuk Meningkatan Hasil Belajar Mahasiswa pada Perkuliahan Dinamika Sistem
}

\author{
Nurwulan Fitriyanti', Reza Fauzi Iskandar ${ }^{2}$ Ahmad Qurthobi ${ }^{3}$ \\ 1. Program Studi Teknik Fisika, Fakultas Teknik Elektro, Universitas Telkom \\ E-mail: nurwulanf@telkomuniversity.ac.id
}

\begin{abstract}
ABSTRAK
Tujuan dari penelitian ini yaitu untuk mengetahui pengaruh dari penerapkan model pembelajaran inkuiri terhadap hasil belajar mahasiswa pada mata kuliah dinamika sistem, metode penelitian berupa Penelitian Tindakan Kelas (PTK) yang dilakukan sebanyak 2 siklus dan setiap siklus masing-masing 3 kali pertemuan. Adapun sampel dalam penelitian ini yaitu mahasiswa TF-38-02 di Prodi Teknik Fisika Universitas Telkom yang berjumlah 43 orang. Data hasil belajar kognitif mahasiswa diperoleh melalui tes uraian, sedangkan data hasil belajar afektif dan psikomotor diperoleh melalui lembar observasi. Hasil yang diperoleh dari penelitian ini yaitu hasil belajar kognitif mahasiswa dengan menggunakan model pembelajaran inkuiri pada siklus 1 memperoleh nilai N-Gain yaitu 0.52 dan pada siklus 2 yaitu 0.45 ,. Sedangkan untuk hasil belajar afektif rata-rata kelas mengalami peningkatan dari $85 \%$ pada siklus 1 menjadi 93\% pada siklus 2. Hal yang sama untuk aspek psikomotor rata-rata kelas pada siklus 1 yaitu $81 \%$ pada siklus 1 meningkat menjadi $88 \%$ pada siklus 2 . Dari hasil penelitian tersebut dapat disimpulkan bahwa adanya pengaruh dari penerapan model pembelajaran inkuiri terhadap peningkatan hasil belajar mahasiswa.
\end{abstract}

Kata kunci: Model Pembelajaran Inkuiri, Hasil Belajar, Dinamika Sistem

\begin{abstract}
The purpose of this research is to find student learning outcome by applying the inquiry learning model for System Dynamic subject. The research method in the form of Classroom Action Research which is done in 2 cycles and 3 meetings for every cycle. In this research, the samples are 43 students of the Department of Engineering Physics, Telkom University, which become sample of this research. Student cognitive learning outcomes data were obtained through description tests, while affective and psychomotor learning outcomes data were obtained through observation sheets. The results obtained from this study, in the form of cognitive learning outcomes of students using inquiry learning models, are $N$-Gain values of 0.52 in the first cycle and 0.45 in the second cycle. Whereas for affective learning outcomes, there was an increase in the average results per class, from $85 \%$ in the first cycle to 93\% in the second cycle. The same thing for the psychomotor aspect, the class average in the first cycle was $81 \%$ and in the second cycle increased to $88 \%$. Based on the results obtained in the study, it can be concluded that the application of the inquiry learning model has an influence on improving student learning outcomes.
\end{abstract}

Key word : inquiry learning model, learning outcomes, System Dynamic

Received: 23 Januari 2019 ; Accepted: 1 Februari 2019 ; Published: 4 Februari 2019 


\section{PENDAHULUAN}

Dinamika sistem merupakan disiplin ilmu yang mempelajari pemodelan matematis, simulasi dan analisa proses untuk memahami perilaku sistem terhadap waktu. Pada dinamika sistem akan diperkenalkan dasar pemodelan sistem fisis menggunakan fungsi transfer dan fungsi ruang keadaan serta menerapkannya pada kasus-kasus sistem mekanika translasi, mekanika rotasi, elektrik, elektromekanik, termal, pneumatik dan hidrolik. Sistem yang telah dibuat kemudian dilakukan analisa respon transien dan tunak untuk mengetahui karakteristik dinamiknya. Pada mata kuliah ini diperlukan dasar-dasar persamaan differensial Biasa (PDB), transformasi Laplace, dan sinyal.

Permasalahan yang sering ditemui cukup beragam, seperti kesulitan dalam memahami aplikasi transformasi Laplace dalam kasus pemodelan sistem, analisa diagram objek bebas, bahkan masih terdapat kesulitan dalam menerapkan hukum-hukum dasar fisika. Salah satu upaya untuk menyelesaikan permasalahan tersebut, maka dilakukan suatu inovasi pada proses pembelajaran yaitu melalui menerapan model pembelajaran inkuiri pada mata kuliah dinamika sistem.

Menurut Sanjaya (2011) bahwa model pembelajaran inkuiri merupakan sebuah model yang lebih menitikberatkan pada proses berpikir baik secar analitik maupun kritis untuk mencari dan menemukan sendiri jawaban dari suatu masalah yang dihadapi. Pada model pembelajaran inkuiri, proses pembelajaran terfokus kepada kemampuan siswa (student centered) dalam menemukan jawaban dari suatu permasalahan sehingga siswa dapat terlibat aktif dalam pembeajaran. Tujuan dari model pembelajaran inkuiri adalah mengembangkan kemampuan mahasiswa dalam berfikir secara logi dan sistematis (Anam 2015). Sehingga hal tersebut dapat meningkatkan hasil belajar mahasiswa. Adapun hasil belajar yang dimaksud meliputi hasil belajar pada aspek kognitif, afektif, dan psikomotor (Arikunto.2015)

Adapun hasil penelitian yang mendukung terkait efektifitas pembelajaran dengan menggunakan model inkuiri, diantaranya penelitian P. Silitonga, dkk (2016), menyimpulkan bahwa keterampilan proses sains siswa yang mengunakan model pembelajaran inquiry training lebih baik dibandingkan siswa dengan model pembelajaran konvensional. Menurut T.F. Sudarman, dkk (2016) hasil penelitiannya bahwa kemampuan mahasiswa dalam memecahkan permasalah fisika pada siklus 1 dan siklus 2 mengalami peningkatan melalui penerapan model pembelajaran inquiry training berbasis just in time teaching (jitt). Hasil penelitian dari D. L. Putra, dkk (2016) menyebutkan bahwa hasil belajar siswa pada ranah pengetahuan dan keterampilan kelas eksperimen lebih baik daripada kelas kontrol. Selanjutnya L Nurmayani, dkk (2018), pada hasil penelitiannya menyimpulkan bahwa hasil belajar fisika pada peserta didik mengalami peningkatan melalui model pembelajaran inkuiri terbimbing.

Berdasarkan latar belakang masalah dan potensi model pembelajaran inkuiri yang telah dipaparkan diatas, maka penelitian ini bertujuan untuk mengetahui bagaimana pengaruh model pembelajaran inkuiri terhadap hasil belajar mahasiswa pada mata kuliah dinamika sistem.

\section{METODE PENELITIAN}

Metode penelitian yang diterapkan merupakan penetilian tindakan kelas (classroom action reseach) dengan desain penelitian menggunakan model spiral Kemmis dan Mc. Taggart. yang diilustrasikan pada gambar 1

Penelitian tindakan kelas ini dilakukan di Program Studi Teknik Fisika Fakultas Teknik Elektro Universitas Telkom semester ganjil tahun ajaran 2016/2017 dengan Subjek penelitian yaitu mahasiswa Prodi Teknik Fisika semester V (Lima) pada kelas TF-38-02 yang berjumlah 43 Mahasiswa. Tindakan dilakukan sebanyak dua siklus, dan setiap siklus dilakukan sebanyak 3 kali pertemuan kelas. 


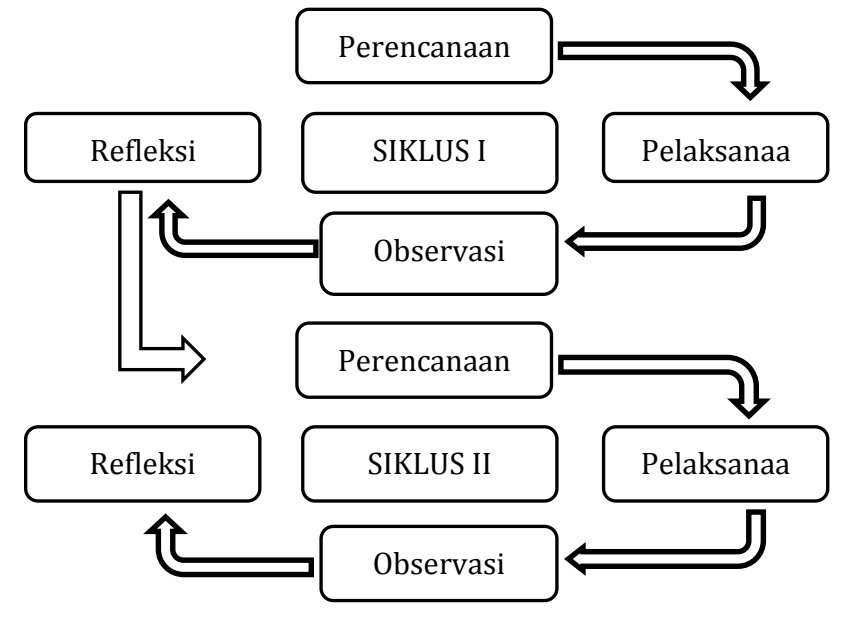

Gambar 1. Model spiral Kemmis dan Mc. Taggart

Adapun jenis data yang diambil pada penelitian ini yaitu berupa data kuantitatif dan data kualitatif, sebagai berikut :

\section{a. Data kuantitatif}

Data kuantitatif yang diambil berupa data hasil belajar mahasiswa pada ranah kognitif, yang dilaksanakan pada saat pretes dan postes setiap siklusnya, kemudian dihitung N-Gain, uji normalitas dan hipotesis dengan menggunakan aplikasi SPSS.

\section{b. Data kualitatif}

Data kualitatif berupa data hasil belajar afektif dan psikomotor mahasiswa dilakukan melalui lembar Observasi kinerja mahasiswa berfungsi untuk mengetahui hasil belajar mahasiswa pada Aspek Afektif dan Psikomotor. Instrumen ini berbentuk rating scale, dimana observer hanya memberikan tanda cek list $(\sqrt{ })$ pada kolom yang sesuai dengan aktivitas yang diobservasi.

\section{HASIL DAN PEMBAHASAN}

Penelitian tindakan kelas (PTK) yang telah dilakukan ini bertujuan untuk mengetahui pengaruh penerapan model pembelajaran inkuiri terhadap hasil belajar mahasiswa baik pada aspek kognitif, afektif serta psikomotor. Untuk lebih jelasnya mengenai hasil penelitian, sebagai berikut :

\subsection{Hasil Belajar Ranah Kognitif}

Untuk analisis data hasil belajar kognitif, dimulai dari penentuan N-Gain, uji normalitas kemudian dilakukan uji hipotesis untuk mengetahui peningkatan hasil belajar yang diperoleh mahasiswa, yaitu :

\section{a. Analisis Skor N-Gain}

Data pretes dan postes dari nilai rata-rata kelas pada Tabel 1, menunjukkan peningkatan hasil belajar dengan model inkuiri pada siklus 1 dan sklus 2 .

Tabel 1. Pretes, Postes dan N-Gain

\begin{tabular}{ccc}
\hline & Siklus 1 & Siklus 2 \\
\hline Pretes & 14.29 & 21.22 \\
Postes & 59.64 & 57.29 \\
N-Gain & 0.52 & 0.45 \\
Kriteria & Sedang & Sedang \\
\hline
\end{tabular}

Berdasarkan tabel diatas, hasil belajar kognitif mahasiswa dengan menggunakan model pembelajaran inkuiri, pada siklus 1 dan siklus 2 mengalami peningkatan. Akan tetapi, pada siklus 1 perolehan nilai N-Gain lebih besar dibandingkan dengan siklus 2 . hal ini dikarenakan karakteristik materi pada siklus 2 lebih banyak analisis matematis, sehingga dibutuhkan kemampuan dasar dan nalar mahasiswa lebih baik lagi.

\section{b. Uji Normalitas}

Untuk mengetahui terkait distribusi data normal atau tidak, maka dilakukan uji normalitas pada siklus 1 dan siklus 2 dengan menggunakan aplikasi SPSS, sebagai berikut :

Tabel 2. Uji Normalitas Siklus 1

\begin{tabular}{ccccc}
\hline & \multicolumn{4}{c}{ Kolmogorov-Smirnov } \\
\cline { 2 - 5 } Pretes & Statistic & df & Sig. & Kriteria \\
Postes & 0.151 & 43 & 0.015 & Tidak \\
Normal \\
& 0.135 & 43 & 0.046 & Tidak \\
Normal \\
\hline
\end{tabular}


Tabel 3. Uji Normalitas Siklus 2

\begin{tabular}{ccccc}
\hline & \multicolumn{4}{c}{ Kolmogorov-Smirnova } \\
\cline { 2 - 5 } Pretes & Statistic & df & Sig. & Kriteria \\
Postes & 0.174 & 43 & 0.002 & Tidak \\
& 0.114 & 43 & 0.187 & Normal \\
\hline
\end{tabular}

Pada Tabel 2, baik data pretes maupun postes menunjukkan bahwa nilai sig $<0.05$, sehingga data tersebut tidak normal. Untuk siklus 2 ditunjukkan pada Tabel 3, nilai pretes memperoleh sig $<0.05$ sehingga datanya tidak normal, tetapi untuk postes perolahan nilai sig $>$ 0.05 menunjukkan datanya normal. Karena kedua datanya tidak terdistribusi secara normal, maka untuk uji hipotesisnya menggunakan uji nonparametric dengan uji wilcoxon.

\section{c. Uji hipotesis}

Untuk mengetahui terkait pengaruh model pembelajaran inkuiri terhadap hasil belajar mahasiswa, maka dilakukan uji hipotesis, maka dilakukan uji hipotesis dengan menggunakan uji nonparametric wilcoxon karena distribusi datanya tidak normal. Adapun hipotesis pada penelitian ini :

$\mathrm{H}_{0}=$ Tidak adanya pengaruh penerapan model pembelajaran terhadap hasil belajar

$\mathrm{H}_{1}=$ adanya pengaruh penerapan model

pembelajaran terhadap hasil belajar

$\mathrm{H}_{0}$ jika nilai sig (2 tailed) $<\boldsymbol{\alpha}$, dan $\mathrm{H}_{0}$ jika nilai sig ( 2 tailed) $>\boldsymbol{\alpha}$, dengan nilai taraf signitikan yang digunakan yaitu $\boldsymbol{\alpha}=0.05$. hasil pengolahan uji statistik siklus 1 dan siklus 2 terlihat pada Tabel 4 dan Tabel 5, sebagai berikut:

Tabel 4. UJi hipotesis Wilcoxon Siklus 1

\begin{tabular}{cr}
\hline & \multicolumn{2}{c}{ Postes - Pretes } \\
\cline { 2 - 2 } $\mathrm{Z}$ & -5.713 \\
Asymp. Sig. (2-tailed) & 0.000 \\
\hline
\end{tabular}

Tabel 5. Uji hipotesis Wilcoxon Siklus 2

\begin{tabular}{cr}
\hline & Postes - Pretes \\
\hline$Z$ & -5.712 \\
Asymp. Sig. (2-tailed) & 0.000 \\
\hline
\end{tabular}

Berdasarkan hasil uji hipotesis yang telah dilakukan pada siklus 1 dan siklus 2 diperoleh nilai Asymp. Sig. (2-tailed) yaitu 0.00 yang artinya nilai Asymp. Sig. (2-tailed) $<$, sehingga $\mathrm{H}_{0}$ ditolak atau $\mathrm{H}_{1}$ diterima. Hal ini menunjukkan bahwa terdapat pengaruh penerapan model pembelajaran inkuiri terhadap hasil belajar mahasiswa mata kuliah Dinamika Sistem.

Peningkatan hasil belajar mahasiswa dengan menggunakan model pembelajaran inkuiri ini, dikarenakan dalam pembelajaran inkuiri, mahasiswa dituntut secara aktif dalam mencari dan menemukan pemahaman sendiri terkait materi melalui percobaan, diskusi kelompok serta presentasi dikelas, dengan adanya keterlibatan mahasiswa secara langsug dalam proses pembelajaran sehingga dapat membantu mahasiswa memahami materi yang dipelajari.

\subsection{Hasil Belajar Ranah Afektif}

Pada penelitian ini, hasil belajar ranah afektif yang dilihat dari beberapa indikator yaitu berkaitan dengan hal keseriusan dalam pembelajaran, kerjasama dalam kelompok, dan keberanian mahasiswa dalam menyampaikan pendapat. Adapun hasil belajar afektif siklus 1 dan 2 terlihat pada Gambar 1, 2 dan 3. Sebagai berikut : 


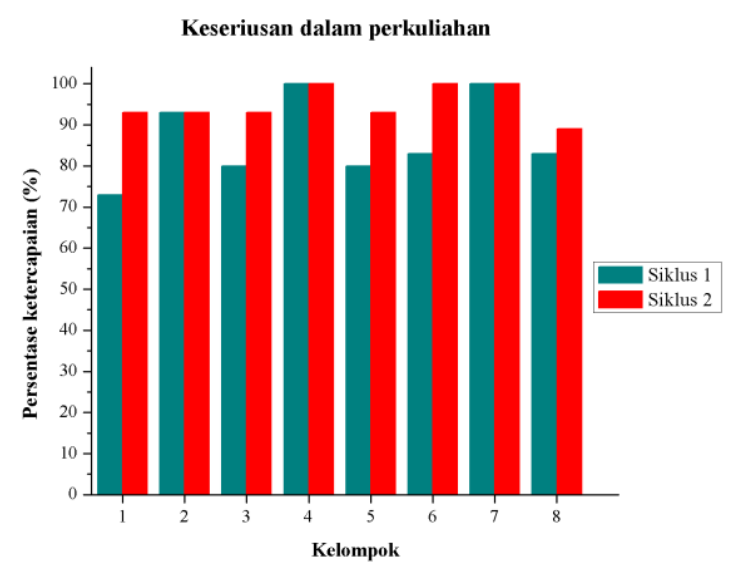

Gambar 1. Keseriusan dalam pembelajaran pada siklus 1 dan 2

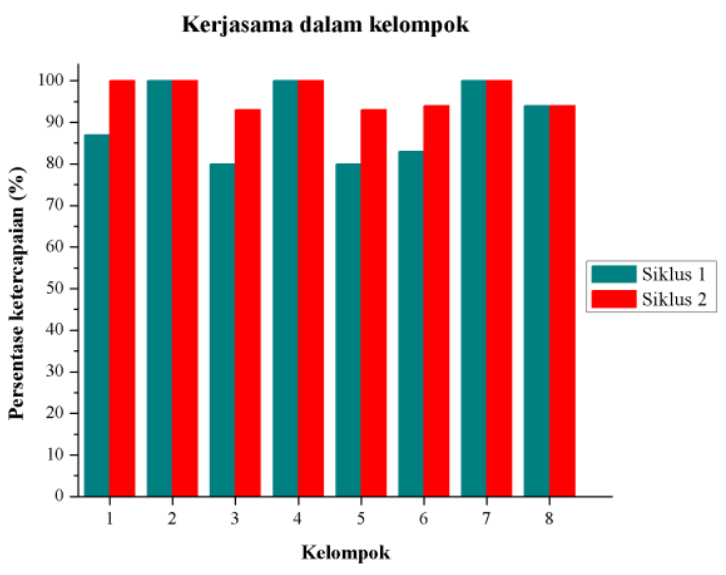

Gambar 2. Kerjasama dalam kelompok pada siklus 1 dan 2

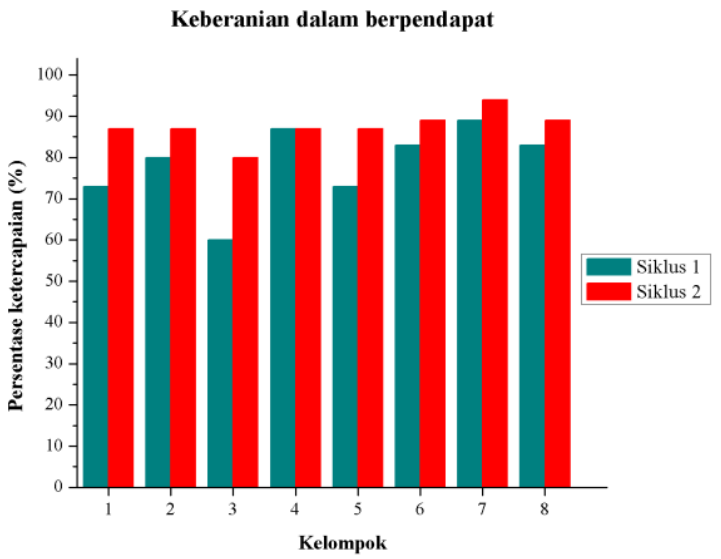

Gambar 3. Keberanian dalam menyampaikan pendapat pada siklus 1 dan 2
Gambar 1-3 menunjukkan bahwa adanya peningkatan hasil belajar ranah afektif mahasiswa dari siklus 1 ke siklus 2, dengan capaian rata-rata kelas yaitu $85 \%$ pada siklus 1 dan meningkat menjadi $93 \%$ pada siklus 2 . hal ini dapat terlihat dari data observasi yang telah dilakukan, adapun kemampuan afektif mahasiswa yang diobservasi terdiri dari keseriusan dalam pembelajaran pada siklus 1 $87 \%$ meningkat menjadi $95 \%$ artinya pada pembelajaran siklus 2 mahasiswa sudah bisa fokus selama pembelajaran, yang awalnya pada siklus 1 masih ada mahasiswa yang bermainmain selama proses pembelajaran sudah tidak terjadi lagi pada siklus 2. Begitu pun dengan kejasama dalam kelompok dan keberanian dalam menyampaikan pendapat juga mengalami peningkatan, artinya pada siklus ke 2 mahasiswa sudah secara aktif terlibat dan mampu memberikan kontribusinya dalam pembelajaran.

\subsection{Hasil Belajar Ranah Psikomotor}

Aspek psikomotorik yang dilihat pada penelitian ini yaitu berkaitan dengan kemampuan melakukan pengamatan, mengumpulkan data, menganalisi data, serta membuat kesimpulan. Untuk data hasil belajar ranah psikomotor pada siklus 1 dan 2 ditunjukkan oleh Gambar 4-7.

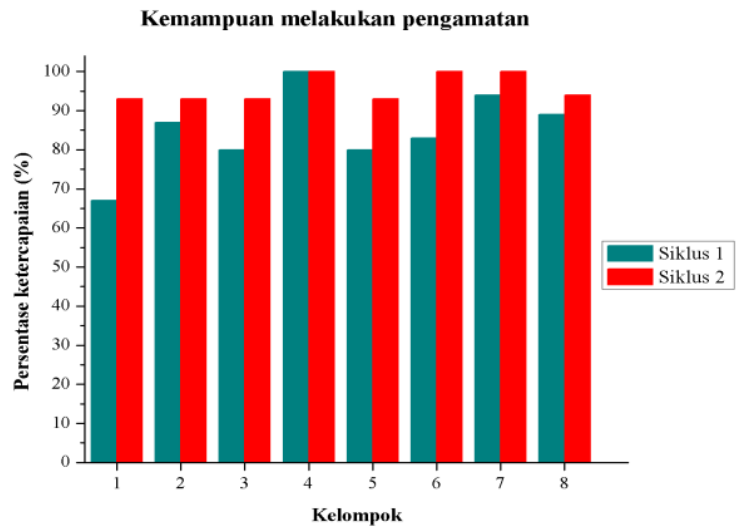

Gambar 4. Kemampuan melakukan pengamatan untuk siklus 1 dan siklus 2 


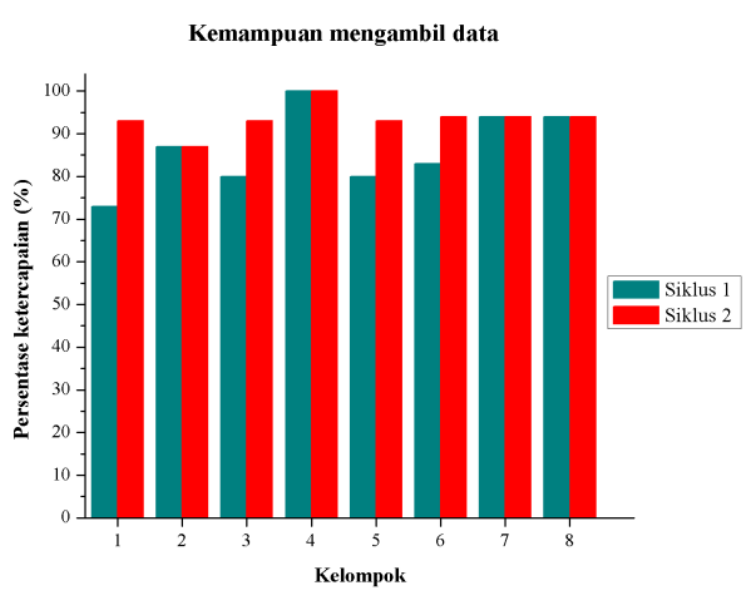

Gambar 5. Kemampuan mengambil data untuk siklus 1 dan siklus 2

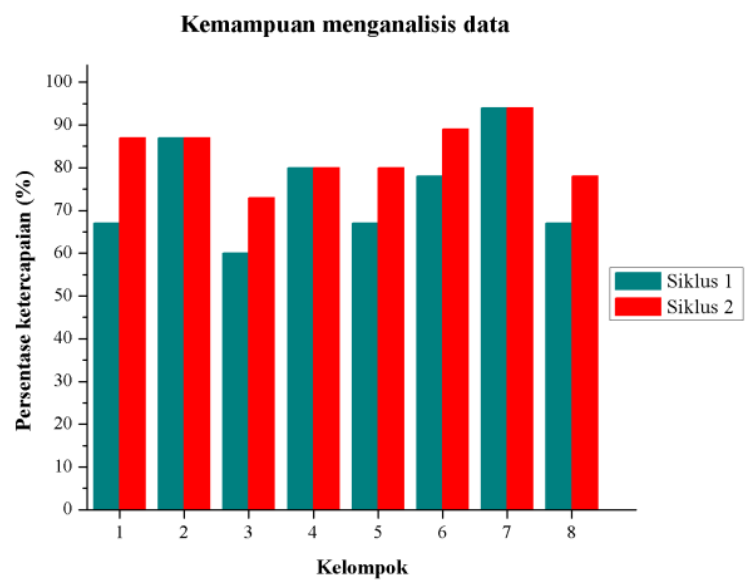

Gambar 6. Kemampuan menganalisis data untuk siklus 1 dan siklus 2

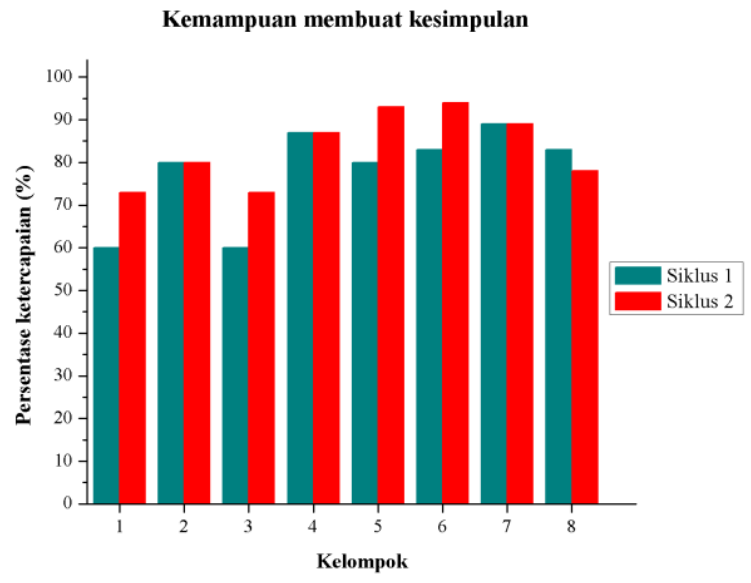

Gambar 7. Kemampuan melakukan pengamatan untuk siklus 1 dan siklus 2
Sama seperti capaian kelompok pada ranah afektif, capaian kelompok yang diperoleh mahasiswa pada aspek psikomotor juga mengalami peningkatan yang baik, dengan ketercapaian pada ranah psikomotor untuk ratarata kelas, yaitu $81 \%$ pada siklus 1 dan $89 \%$ pada siklus 2 . Hal ini dapat terlihat pada gambar 4-7, untuk indikator melakukan kegiatan praktikum dan mengumpulkan data sudah sangat baik diatas $90 \%$ mahasiswa terlibat dalam aktivitas tersebut, hal ini dapat terlihat dari antusias mahasiswa melakukan praktikum elektromekanik, untuk analisis data dan membuat kesimpulan juga sudah mengalami peningkatan dari sebelumnya, hal tersebut dikarenakan dosen selalu memberikan arahan mengenai jurnal yang akan dilaporkan.

Peningkatan aspek keterampilan baik dari afektif maupun psikomotor, sejalan dengan tujuan dari pembelajaran inkuirri yaitu membantu mahasiswa membantu siswa menggali kemampuan intelektual dan keterampilan lainnya yang berasal dari rasa keingintahuan terhadap suatu permasalahan. (Joyce, et al, 2009).

\section{KESIMPULAN}

Berdasarkan analisis data dan pembahasan maka dapat ditarik beberapa kesimpulan kesimpulan bahwa:

1. Peningkatan hasil belajar ranah kognitif mahasiswa dengan menggunakan model pembelajaran inkuiri pada siklus 1 memperoleh nilai N-Gain yaitu 0.52 dan pada siklus 2 yaitu 0.45 , dengan kategori ketercapaian sedang.

2. Ketercapaian hasil belajar ranah afektif ratarata kelas yaitu $85 \%$ pada siklus 1 dan $93 \%$ pada siklus 2. Adapun ketercapaian untuk tiap indikator keseriusan dalam belajar pada siklus 1 yaitu $87 \%$ dan pada siklus 2 diperoleh nilai 95\%, Pada indikator kerjasama dalam kelompok untuk siklus 1 diperoleh 91\% dan siklus 2, dan untuk indikator keberanian dalam berpendapat 
pada siklus yaitu $79 \%$ dan pada siklus 2 diperoleh $87 \%$.

3. Ketercapaian pada ranah psikomotor untuk rata-rata kelas, yaitu $81 \%$ pada siklus 1 dan $89 \%$ pada siklus 2. Sedangkan untuk setiap indikator melakukan pengamatan pada siklus 1 yaitu 85\% dan siklus 2 adalah 96\%, pada indikator mengumpulkan data di siklus 1 diperoleh nilai sebesar $87 \%$ dan pada siklus 2 yaitu 94\%, untuk indikator menganalisis data pada siklus 1 didapat $75 \%$ dan siklus 2 yaitu 83\%, dan terakhir untuk indikator membuat kesimpulan pada siklus 1 diperoleh $78 \%$ dan pada siklus 2 diperoleh $83 \%$, hal ini menunjukkan hasil belajar mahasiswa pada ranah psikomotor mengalami peningkatan dari siklus 1 ke siklus 2 secara variatif di setiap indikator yang diukurnya.

\section{UCAPAN TERIMA KASIH}

Terima kasih kami haturkan kepada Center for Teaching and Learning Excellence (CTLE) Universitas Tekom atas pemberian Hibah Penelitian Tindakan Kelas Tahun Ajaran 2016/2017.

\section{DAFTAR PUSTAKA}

Anam, K. (2015). Pembelajaran Berbasis Inkuiri Metode dan Aplikasi. Yogyakarta: Pustaka Pelajar.

Arikunto, S. (2015). Dasar-dasar Evaluasi Pendidikan. Jakarta: Bumi Aksara

D. L. Putra, dan Z. A. I. Supardi. (2016). Penerapan Model Pembelajaran Inkuiri Pada Materi Suhu dan Kalor untuk Meningkatkan Hasil Belajar Siswa Kelas X SMA Negeri 1 Waru Sidoarjo. Jurnal Inovasi Pendidikan Fisika (JIPF) . 05 (01), 5-10.
Joyce, B., Weil, M., Calhoun, E. (2009). Models of Teaching Model-model Pembelajaran, Yogyakarta: Pustaka Pelajar.

Lia Nurmayani , Aris Doyan, Ni Nyoman Sri Putu Verawati. (2018). Pengaruh Model Pembelajaran Inkuiri Terbimbing Terhadap Hasil Belajar Fisika Peserta Didik. Jurnal Penelitian Pendidikan IPA (JPPIPA) , 4(2).23-28.

Purnama Silitonga, Mara Bangun Harahap, dan Derlina. (2016). Pengaruh Model Pembelajaran Inquiry Training dan Kreativitas terhadap Keterampilan Proses Sains. Jurnal Pendidikan Fisika 5(1),44-50

Sanjaya,W. (2011). Strategi Pembelajaran Berorientasi Standar Proses Pendidikan. Jakarta: Kencana Prenada Media Group.

Teguh Febri Sudarma 1, Yul Ifda Tanjung dan Muhammad Kadri. (2016). Penerapan Model Pembelajaran Inquiry Training Berbasis Just in Time Teaching (JiTT) Untuk Meningkatkan Pemecahan Masalah Fisika. Jurnal Ikatan Alumni Fisika Universitas Negeri Medan 2(1), 35-43. 